Rupkatha Journal on Interdisciplinary Studies in Humanities (ISSN 0975-2935), Vol. 10, No. 1, 2018 Special Issue on "Interrogating Cultural Translation: Literature and Fine Arts in Translation and Adaptation" In collaboration with the Department of English, Amrita Vishwa Vidyapeetham Guest-edited by Dr. Hari M G, Amrita Vishwa Vidyapeetham, Coimbatore, India DOI: https://dx.doi.org/10.21659/rupkatha.v10n1.05 Full Text: http://rupkatha.com/V10/n1/v10n105.pdf

\title{
Revisiting Ethno-nationalism: A Study of Nihal De Silva's The Road from Elephant Pass
}

\author{
Bibhuti Mary Kachhap ${ }^{1}$ \& Aju Aravind ${ }^{2}$ \\ ${ }^{1}$ Research Scholar, Department of Humanities and Social Sciences, Indian Institute of \\ Technology (ISM), Dhanbad 826004, Jharkhand, India. Email: vibhutiz119@gmail.com \\ ${ }^{2}$ Assistant Professor, Department of Humanities and Social Sciences, Indian Institute of \\ Technology (ISM),Dhanbad 826004, Jharkhand, India.Email: aaravind13@gmail.com
}

Received September 27, 2017; Revised December 11, 2017; Accepted December 30, 2017; Published February $04,2018$.

\begin{abstract}
Sri Lanka in the last decade witnessed a catastrophe of incidents that blurred the lines of nationalism. The two ethnic communities of Sri Lanka the Sinhalese and the Tamils suffered differences that later transformed into a Civil War (1983-2009). The post-independence era brought out 'nationalism' within the country but turned ethnic in a short course of time. Therefore the theme of ethno-nationalism is prevalent in Sri Lankan English literature. Literature of the War also produced biased and chaotic pictures of the event. Ethno-nationalism possessed the island and left it bruised and dismantled to which we find evidences in texts. Sri Lanka had not imagined a twenty six year long War therefore its aftermath left the country to figure out the dilemma yet to be produced. This paper will focus on the subject of ethnonationalism in selected Sri Lankan fictions. Its aim will be to objectify the ethno-nationalist war (Civil War) through the theories of nationalism and ethno-nationalism in the fictions. The term 'revisiting' here emphasizes the actions of people who had shown nationalistic fervor during the War and how the author has (re)presented it in fiction. As literature in particular fiction (here) has been gestated and created to enlighten how ethno-nationalism is perceived in Sri Lankan fictions and in particular Nihal De Silva's novel The Road from Elephant Pass. It highlights the dual aspects of ethnicity through its protagonists who is a Tamil and Sinhalese respectively, their love story which compel them to dissolve the line of animosity.
\end{abstract}

Keywords: Ethno-nationalism, Tamil, Sinhalese, war and nationalism.

\section{Introduction}

“...the study of ethnicity, nationalism, and migration is vibrant and dynamic. The sheer number of topics is impressive, and many of those topics are either relatively new phenomena or reflect significant recent changes in their subject matter". -(Maas).

"It is nationalism which engenders nations, and not the other way round.” (Gellner, 2013, p. 54)

Reading ethno-nationalism persuades us to glance at theories of nationalism as the European concept, and also as the pioneer to nationalism, nationhood and State. Scholars like Benedict Anderson, Gellener, Tom Nairn and Partha Chatterjee have dispensed with the topic evidently.

(C) Authors. Published by AesthetixMS under a Creative Commons Attribution Non-Commercial 4.0 International License (http://creativecommons.org/licenses/by-nc/4.0/). 
While Hetcher has defined nationalism as a "popular protest against oppression" (Upreti, 2006, p. 537). Gellner defined nationalism as "primarily a political principle that holds that the political and the national unit should be congruent" (2013, p. 1). Ethnic uprisings lead to ethno-nationalism which also creates racial divide. "Often the terms 'race,' 'nation' and 'ethnicity' is used interchangeably and therefore indicate an implicit or perceived connection between these concepts. "The term 'race' in English incorporates several meanings including ethnicity, tribe, clan and nationality" (Cheran, 2003, p. 19). Somehow the race divide also coincides with religion. "In nationalist doctrine, language, race, culture and sometimes even religion constitute different aspects of the same primordial entity the nation" (Kedourie, 1994, p. 49). There were attacks on Hindu temples in 1992 in Sri Lanka by the Sinhalese Buddhists (Rieffer, 2003, p. 1-2) to tamper and hurt the strength and belief of the Tamils. Dharamapala (1864-1933) the Sinhala-Buddhist revivalist inoculated Buddhist-Sinhala nationalism in Sri Lanka because of which the position of Buddhism as a non-violent religion is contested. Protecting one's culture and religion leads to disagreements, as in the case of Dharampala and other Buddhist monks. Therefore Hindu religion had nothing to do with 'Sri Lankan nationalism' but Buddhism had. 'Sinhalese Buddhist nationalism was foregrounded by Dharampala. “... the movement led by Dharmapala was blatantly hostile to the Tamils, and to Hinduism and Islam" (Cheran, 2003, p. 82). He once said "[t]he Sinhalese are a unique race in-as-much as they can boast that they have no slave blood in them and never were conquered either by the pagan Tamils or European Vandals. ... the Sinhalese stand as the representatives of Aryan civilization" (Dharmapala 1965). Through this we can trace the retaliation in his tone for other ethnicities and religions very evidently.

In Sri Lanka the two ethnic communities Sinhalese and Tamils protested against each other for their race because after independence the Tamils were deprived of many facilities which they enjoyed during colonial rule. Like the 'Only Sinhala Act' of 1956 which deprived them of using Tamil language at government spaces. Earlier English was the Official language of the island nation. Also the "Standardization Policy" that limited the Tamil access to higher education. It was implemented in order to decrease regional disparities that had persevered from the colonial times (Hettige, 2004, p. 122). The result was revolutionary. Tamil youths revolted against the raised quota in certain courses for the Sinhalese. The Tamils during British rule had access to English education which helped them prosper through employment. Therefore Tamils the minority community saw the "Standardization Policy" against their betterment. It was then that the demand for a separate homeland towards the North-East part of the country for Tamil speaking community in Sri Lankan found rigor. The uninterruptedly ostracized 'Sinhalisation' isolated the minority Tamils and the brutality of the centralization and consolidification of power by the Sinhala aggravated the suffering of the Tamils (Rampton, 2011, p. 261).

The literature of war in Sri Lanka produced fictions and poetry that talked, lamented the pandemonium generated by the war. There were fictions in languages such as Sinhalese, English and Tamil. And they somehow soothed the people in crises. Recent writers focused on the themes of Civil War and the pathos recollected in the memories of the survivors. The history of English literature in Sri Lanka can be traced back only to the beginning of the last century. It was only after attaining independence in 1948 that English literature added a gravitas to the Sri Lankan literature and a handful of works in English with writers like, S. J. K. Crowther, Weerasooriya and Jinadasa Vijayatunga were published (Goonetilaike, 2007, p. 10).

Literature became an aspect of politics in Sri Lanka during insurgency and it was War literature that added to the literary grandeur. Earlier writers penned on limited theme such as rural life. With the subject of War the readership increased and the publication of books also 
augmented. Earlier there were only the elites who took to writing in English and publication was also an issue. But writers did not write about challenging the facts and they arguably lacked the voice of protest, though there was some isolated attempt at portraying the grievances of war. The only theme that could be seen repeatedly in all the novels was stories about war and some nonfictions have raised voices or rather given an account of both the parties respectively. The conflict between the Sinhalese and Tamils or rather to be mentioned as the Sri Lankan government which was Sinhalese oriented and the Tamils collaborated with several partners to win against each other. This paper examines Nihal De Silva's The Road from Elephant Pass (2003) that narrates the story of two culturally different people divided by ethnicity but united by circumstances; both are nationalists, rather ethno-nationalists, since both are fighting for their own respective ethnicities against each other in Sri Lanka.

\section{Ethnic deliverance: Spectating the novel}

The Road from Elephant Pass ii enquires about 'ethnic racism' which delivers ethno-nationalism in a war stricken country like Sri Lanka where the trust of the populace has started to collapse. It is highly imperative to discuss nationalism before moving to the concepts of ethno-nationalism. "It is generally agreed that nationalism as an ideology emerged in the wake of the French Revolution. As one treks through the history of nationalism in Europe, the rise of ethnic nationalism and its origins in the thought of German Romanticism, ..." (Dusche, 2010, p. 37). Sadanand Menon makes a remark on nationalism persuaded by culture he says

"culture and nationalism have ever been close allies. Culture has always set up the contours for national movements and nations have used culture as a convenient flag to wave in ideas of superiority or exclusivity" (2016, p. 110).

The novel indicates ethno-nationalism as it emerged out of insurgency gestated by the Liberation Tigers of Tamil Eelam ${ }^{\text {iii }}$ (LTTE or Tigers). Ethno-nationalism is usually associated with ethnic identity. Ernest Gellener epitomizes 'nationalism against ethnic conflicts'. He further says that 'ethnic identity' can be taken as ethnic nationalism because ethnic identity is followed by conflict and it impedes progress (Cheran, 2003, p. 28). The Tigers fighting with assurance did impede progress but the 'all Sinhalese government' compelled them to act against the State. The ideological framework or the 'Repressive State' scrubbed away the idea that Tamils could grow and flourish under Sinhalese. "For Gellner and Nairn, 'uneven development' has been the motor of ethnic movements. ...The importance of 'uneven development' lies largely in the potential for cultural cleavage" (Cheran, 2003, p. 27). As discussed above it is all an outcome of restriction of progress and that is the reason why there is cultural discrimination and imbalances. Industrialization in Sri Lanka meant restricting the agricultural laws for only the minorities advanced the nationalist fervor which was cultural and ethnic because when ethnicity is the ideal idea behind nationalism it results in ethno-nationalism.

The novel begins with the introduction of a woman who is described as a Tamil named Kamala Velaithan "a senior woman activist who has turned against the movement. She claims to have vital information and wants to negotiate a deal ..." (De Silva, 2006). She is quite audacious and likes her "Tamil deferential" which offends Wasantha Ratnayake the Captain who arrests her "at the Checkpoint near Pallai, on the main road from Elephant Pass to Jaffna" (De Silva, 2006, p.). He is given the responsibility to take her to Colombo. Kamala makes such ethnic remarks throughout the novel which proves her nationalistic attitude towards her ethnicity. The vital information is about their "Leader" Prabhakaran ${ }^{\text {iv }}$ who will be present at an event on a specific 
date. She manages to persuade the officers to take her to Colombo in order to give the information directly to the DMI (Director of Military). They begin to travel in a jeep on the same evening Kamala came to the Checkpoint. The very first day they are attacked by the Tigers. "They blew a culvert near Mirusuvil" when we were a couple of hundred yards from it. ..." (De Silva, 2006, p. 8). Kamala suggested that they should turn back. A moment later Kamala informed that the Pallai region and the camp will witness "... major attack on Elephant Pass tonight. The camp is already surrounded. We will not be able to get through.” (De Silva, 2006, p. 9). Wasantha feels as if it is a trap but immediately dispense the idea. In course of turning back they are attacked again, this time "Gunfire raked the Vehicle ... the impact tipped the vehicle on its side with a resounding crash" (De Silva, 2006, p. 11-12). They were unconscious specially Wasantha but managed to walk. His conversation with Kamala proves his determination to stop the Tigers, he says "Elephant Pass is our best chance' ... We'll have to find a way through your lines." But immediately he hears "the unmistakable boom of $152 \mathrm{~mm}$ cannon, and the rattle of small arms" (De Silva, 2006). After this incident they settle to walk and reach Wanni which is 75 miles away from where they stand now. Their conversations reveal that Wasantha is keen to know the date when their leader will be at a certain place. Kamala answers, it is Wednesday sixth of April and only 10 days left. They make a plan and Kamala asks Wasanth to act as a victim of Elephant Pass attack and names him Wasu Velaithan. Wasantha tries to agree "I tried to nod and regretted it" (De Silva, 2006, p. 30). The attitude behind Wasantha's nod is obvious as he has no choice. But the idea of becoming a Tamil was unacceptable. His nationalism for his State seems shaken. Therefore he said he regretted the 'nod'. Tamil identity is unacceptable to a Sri Lankan Army soldier like Wasantha. The mere act of presenting oneself as a Tamil in Sri Lanka is contestable. This adds to the ethno-nationalism concept. In between there are incidents while the two are moving towards Colombo by crossing the rebel territory. One such incident is when the two steal a motorcycle and are driving towards Wilpattu. Two policemen stop them to question. Wasantha in a made up Moslem accent speak to the policeman and regards Kamala as her sister-in-law, whom he is going to drop at him. The two policemen make a racial comment "Looks like the Moslem is going to bonk his sister-in-law. The word he used for "Moslem; was an offensive one" (De Silva, 2006). Moslems have been targets of the Sinhalese people prior to the War but since the Sinhalese were so much in animosity with the Tamil minority that they barely paid attention to other communities. Wasantha too marks observations on the Tamils. He says they “... are a straight-faced lot" (De Silva, 2006, p. 61). In the course of travelling to Colombo the two encountered EPDP a Tamil ethnic group like the LTTE whose leader was murdered by Prabhakaran. Now EPDP aligned with the government and acts as an anti-LTTE Tamil group. They surpass the trouble and entre the dry Zone and jungles. These jungles are dense and wild animals are the enemies prevalent now. Wasantha and Kamala survive all sorts of dangers, hunger and injuries. It was amidst all this when Kamala tells Wasantha about his family. Her father died in 1983 post $23^{\text {rd }}{ }^{\text {July }}{ }^{v}$ riot. He was killed by Sinhalese men. Kamala in distress says "the Sinhala have no right to peace after what they did to my family" (De Silva, 2006, p. 133). Such incidents were very common in Sri Lanka during the Civil War. They have now entered the jungle. The jungle is again as dangerous as the rebel territory because leopards and scavengers are moving in a candid manner. While passing the jungle they are attacked by the members of the EPDP whom they had robbed earlier. They manage to escape. Later their conversation in the jungle again returns to the Tamil-Sinhala conflict. Wasantha makes a remark "The Tamils claim about one third of the land area of the country as their 'traditional homeland'. ... to demarcate boundaries of the so-called homeland are to my mind dubious to the point of absurdity. That is why we are at war" (De Silva 2006). To which she replies that may be in ancient times the occupants had been Tamil people. To which Wasantha had no answer as he is not sure about the facts. Again Wasantha like a true Sinhalese nationalist questions Kamala 
"Can you explain to me the logic basis on which the Tamils claim a traditional homeland?' I asked with exaggerated courtesy. 'How can $8 \%$ of the population justify a demand for one third of the land area of this country?' She replied 'Our people have occupied these regions from antiquity. ... 'the Sinhala were brought to these parts only under colonization schemes. It is well documented that these schemes were introduced by Sinhala governments to take away our lands and dilute our political strength." (De Silva, 2006, p. 151).

Wasantha this time comes up with an argument that the Mahavansa ${ }^{\mathrm{vi}}$ holds proofs to the oldest settlers of Sri Lanka. However Kamala disposes the proof as the Mahavansa provides "accurate religious history but surely biased and unreliable when dealing with secular matters" (De Silva, 2006, p. 152). Certainly, their argument does not reach to any conclusion. Later Wasantha springs up with an idea which might sound impractical but due to lack of options it could be one. He says that all civilian Tamils should be put in a camp until the Army swipes off the Tigers. Here a narrow diminishing line of Sinhalese nationalism could be traced as Wasantha is not anti-Tamil. He is anti-LTTE and against their idea of a separate nation. Kamala informs Wasantha that they too compel their cadres to avoid civilian violence but their cause sometimes demand casualties. She further says that their leader Prabhakaran asked "his cadres to kill him if he ever gives up his call for Eelam ..." (De Silva, 2006, p. 202). We find ethno-nationalism prevailing to the level of giving away their lives which is not uncommon. Such activist persona had existed everywhere in the world always.

Kamala and Wasantha walking cross-country finally reach Colombo on $3^{\text {rd }}$ April 200o. A lot of incidents take place between them. They hated each other when they started the journey. However the scenario is different now. Both the enemies representing two very different ethnic communities have dissolved their differences. Wasantha says "We combine pretty well don't we? Too bad we play for different teams!" (De Silva, 2006). They fall in love and desire for the wellness of the other. They reach Colombo and stay at a friend's place in the suburbs of Colombo and leave for the Headquarter the next morning. When they reach, Kamala reveals to Wasantha that "It's a trap.'...Ajay Devanand! He'll be there with a team of Indian journalists' she said. Dr. Devanand is a highly respectable social worker from Chennai India. ... he had often criticized the LTTE for human rights abuse"(De Silva, 2006, p. 401). The LTTE has invited him to inspect the territory to satisfy him. Instead the real motif of the LTTE is to kill him. They want the government to kill him in order to gain the Indian opinion against the Sri Lankan government.

Wasantha is agitated but controls himself only because of his love for her. He is not worried about the lie or trap his area of concern is Kamala's safety. Where would she land with this false information? She will be killed. "I need time! Five minutes alone to come up with some plan but there was no time left. ... (De Silva, 2006, p. 403) 'What is the nature of the information?' 'The precise location of a building where Prabhakaran will be, on a specific day and time.' ... And what does she want in return for this information?' (De Silva, 2006, p. 404). Looking into the promptness of the situation Wasantha answers "'A new identity, passport, visa and passage to Canada,' I said. 'And a protective custody till she leaves." (De Silva, 20o6, p. 404). His love for Kamala disables him to tell the truth to the higher authorities. In a way he betrayed his people. The situation was such that one can detect ethnic nationalism dissolving. Even Kamala betrays her people by confronting the truth before Wasantha. They both know that the information will have an impact on the government as well as the Tigers. The day of the attack arrives and Prabhakaran is fortunate, he survives. However Colonel Srikantha of the LTTE is killed along with other cadres. Wasantha manages to convince Kamala about his decision to get back to the army 
camp and be safe. One behavioral change is observed in Wasantha. He desparatly wants to stay with Kamala in his last meeting he tries to convince her. Kamala as a strong woman explains Wasantha about the consequences they might have to face with the decision uniting. Wasantha's thoughts pour out and therefore he wanted to rage against the forces that threatened them (De Silva, 2006, p. 425). What is debatable is the reversal of the situation. Earlier Wasantha had animosity towards the Tigers because of his nationalistic zeal towards the nation. However now out of love and safety for Kamala he wants the Tigers dead. She is sent to Canada by the Sinhala government. And Wasantha goes back to Elephant Pass to fight and goes missing on $29^{\text {th }}$ April 200o. In a letter to her mother the Brigadier wrote "... your son, Captain Wasantha Ratnanayake, has been declared missing ...” (De Silva, 2006, p. 428). It was the Elephant Pass from where Wasantha went missing. There is suspicion to his missing because he had travelled nine days on foot and was very well aware of the expanse. This leaves the readers to make one's own conclusions whether Wasantha on purpose went missing or the circumstances were certainly bad that he actually went missing. This novel is all about expedition and love.

The love and passion that made the two forget their ethnicity loyalty towards the nation. It is also an encyclopedia to survive the most extreme conditions on land. The novel also makes an attempt to contradict the present nature of ethno-nationalism through the two protagonists. Capturing the intimacy and ruthlessness at the same time De Silva brings forth the narrow line between the ideology of the Tigers and the Sinhalese army. There is ground-breaking and prototype shift on the perception of nationalism in the novel which later discloses the nature of nations where individuals built their own arena of nationalism to fight their enemies (Rampton 2011, p. 246). Other than that, mainstream nationalism has its own approaches which cannot be seen as it is mostly an underlying structure. The power politics could be said to be, one of those underlying structures in case of Sri Lanka. It all began with the university admission, seats and the 'Language Act Policy' of 1956 also known as "Official Language Act No. 33 of 1956" or "Only Sinhala Act". In Sri Lanka soon after independence the Sinhalese government brought the 'Language Act' 1956 which meant that Sinhala will be the official language of the country (Syed, 2007, p. 209). Tamils of the north hardly knew Sinhala. But language policy along with it bought the university seats reserved for Sinhalese speaking students. Tamils who were favored by English were well educated and restored to fine positions and had good business all over Sri Lanka. Whereas Sinhalese were not much into English education which deprived them from certain jobs. This made the government thoughtful towards the ethnic majority. And hence the above mentioned policies were introduced which would bring the Sinhalese to the power structure and the center. Language policy bought rage which the Sri Lankan English literature seems to witness. In fiction like July by Karen Roberts there are episodes of vernacular conflicts and violence. "Priyanthi one of the Protagonist is asked to prove her ethnicity "I am Sinhalese (she says), ...Say "baaldiya" ... 'Tamils can't say the "b" ... they say "vaaldiya" (Roberts, 2001, p. 347). Language which is a prime part of ethnicity acts as a tool to protect lives and also acts as a weapon for destruction. Similarly in Nayomi Munaweera's novel Island of a Thousand Mirrors one of the protagonist's Saraswati learns the language of other ethnicity in order to destroy them "The Colombo shopkeepers speak Sinhala at me and I reply effortlessly and smile back at them. I own their tongue as if I have been brought up in this smoky, crowded city instead of in quiet northern places" (Munaweera, 2013, p. 188). 


\section{Deciphering aspects of Ethno-nationalism in the novel}

The inspiration to stand for one's own culture, tradition and socio-political aspects could be summed up to be ethno-nationalism in its basic form. Language not religion defines the ethnicity. Example would be South Indian Moslems and Sri Lankan Tamils. For South Indians like in Kerala anyone is a Malyali first then a Moslem, similarly in Sri Lanka all Tamils are Tamil first then Christians or Hindus (Cheran, 2003, p. 23). Likewise in the novel to be discussed, raises questions on the very existence of ethno-nationality. The two protagonists Wasantha and Kamala fall in love despite their hatred for each other's ethnicity. Wasantha a Captain in the Sri Lankan Army and Kamala a Tiger ${ }^{\text {vii }}$ do not forget their spirit of nationalism until the frail instant arrives when they both realize that death is awaiting the other. Wasantha in agitation and intention to save Kamala does not stop her from telling the lie; he says "Even if you tell them the truth now, it will make no difference,' I said desperately, trying to calm myself. 'they will still interrogate you as a hostile. You will suffer ... permanent damage.” (De Silva, 2006, p. 402). Ethno-nationalism has been objectified. The objectification is based on the love story that began on the journey from Jaffna to Colombo. The novel encompasses 'object' which is nation. Demand of a separate 'state' by the Tamils in the north-east region of Sri Lanka was stated unethical and irrational by the state. De Silva confuses its readers, for at some instances he portrays Wasantha as a liberal person whose duty is towards the country and its people irrespective of their identity. He says 'what morality are you talking about? The civilians we saved that day were Tamils, every one of them,' I told her. 'Don't innocent victims have rights as well? We had a duty to protect them. We saved their lives: ..." (De Silva, 2006, p. 196). Objectification of ethno-nationalism leads to confusion yet again. Arguing that a Sinhalese mob attacks the Tamils is it the government that intended to attack. In the novel Wasantha and Kamala debate to the reason of attack by a Sinhala. Kamala's family was killed by Sinhala men so should the government be responsible or those gang of Sinhala men. He says "You say the Sinhala attacked your family,' I said as gently as I could,' but it wasn't the Sinhala nation was it?', ... (De Silva, 2006, p. 321). But what is important is that the government is indirectly responsible towards this violence whereas Sinhalese men are directly responsible. But De Silva allows Wasantha to stop the argument at a place where the gang of Sinhala men kills a Tamil family and makes the argument that it is the men alone responsible and not the government. But in Sri Lanka all the atrocities that took place during 1983 after the "black July ${ }^{\text {viii, }}$ government was responsible because it could not control the violence. Tigers were no less they were as brutal as the government. For Prabhakan was compared to Gotabaya Rajapaksa ${ }^{\text {ix }}$. "Prabhakaran and Gotabaya were two sides of the same coin. ... both prepared assiduously for what they believed would be their final confrontation - albeit that each predicted an opposing outcome - in what is now known as Eelam War IV" (Weiss, 2012, p. xxvi).

Since Gotabaya and Prabhakaran represented ruthlessness they also represented two very important communities the Sinhalese and the Tamils. And as the Tamils were fighting against the state for a separate nation they undermined themselves with nation community (minority). To present a clear picture the 'race conflict' can be mirrored through Anderson's idea of "community" which is "imagined". Anderson says

Imagined because the members of even the smallest nation will never know most of their fellow members meet them or even hear them, yet in the mind of each lives the image of their communion [and] a community, regardless of the actual inequality and exploitation that may prevail in each, it is always conceived as a deep horizontal comradeship. Ultimately it is this fraternity that makes it possible, over the past two centuries, for so 
many millions of people, not so much to kill, as willingly to die for such limited imaginings (1998, p. 15-16).

The Tigers stood for all the fellow Tamils and fought against the state irrespective of their caste or religion. They too like Anderson said, are "imagined" because one is not going to meet every person of that particular community. Tamils as the minority community in communion to all fought against the majority community. All Tamil families contributed to the Eelam. They gave their children to this ethno-nationalist fervor. And Prabhakaran led every Tamil to dream and achieve the dream of living in a free state and Tigers were ready to sacrifice their lives for their community. The Tamils demand for a separate state was the product of negligence and deprived rights to the Tamils. The rights deprived were University education because during British rule the Tamils were favored for English education and so the Tamils secured good jobs but as Sri Lanka got independence the Sinhalese government restricted rights to admission for the Tamils. They demanded Sinhalese language as compulsion. "A National Education Commission in 1961 recommended religious quotas to university admissions and public service to compensate for presumed Buddhist disadvantages" (Peebles, 2006, p. 113). Sri Lanka even observed forced nationalism ${ }^{\mathrm{x}}$. After the Civil war ended in 2009 the government of Sri Lanka announced a mandatory tradition which was to sing the national anthem in Sinhalese. In jails across Sri Lanka the convicts are daily compelled to sing the national anthem in Sinhalese because most of the people are Tamil who have been arrested on the charges of terrorism (Terrorism Prevention Act) (Mohan, 2014, p. 306).

Locating ethnicity in nationalism in Sri Lanka leads to Sinhala nationalism as well as Tamil nationalism which can be considered under ethno-nationalism. Rampton in his article quotes Jeganathan and Ismail "the nation - to be precise, those with the power to act in its name has always suppressed its women, its non- bourgeois classes and its minorities” (2011, p. 255). There is reference to Indira Gandhi assassination in the novel which proves the behavioral change of men towards the nation or community. "Do you remember Indira Gandhi and the Sikh problem? ...So one day her trusted bodyguards shot and killed her,' ... 'They were Sikhs first and Indians second!"' (De Silva, 2006, p. 20o). After the assassination the other communities started hunting down the Sikhs all over India as if all were responsible for the killing. To persuade the thought the argument further was "So long as the war goes on, any Tamil may willingly or unwillingly carry out a terrorist act or, at least, work against the state" (De Silva, 2006, p. 199).To ostracize the incident there is a similar case in Sri Lanka but contrastive at the same time. In 1959 the fourth Prime Minister S. W. R. D Bandaranaike was assassinated by a Buddhist monk named Talduwe Somarama and reason being, for the grander and betterment of the country, race and religion. But unlike India there were no counter strikes on the Sinhalese community or the Buddhist monks.

Kamala and Wasantha shared a sexual relationship on the course of nine days and Wasantha questions Kamala "I asked gently: 'Does it still bother you that I am Sinhala?' 'Yes,' she said gravely. 'Yes, it does. In one part of my mind, I am appalled at what I have done.' 'And the other part?' ... I buried my face in her hair. 'I like the smell of you.' 'What smell is that?' She sounded pleased. 'Bar soap and Tamil girl.” (De Silva, 2006, p. 350). There is objectification of body through ethnicity. What is the smell of a particular ethnicity? The idea is interesting as well as difficult. To decode the idea of smell and ethnicity is relevant and can be classified as 'racism'. Ethnicity conclusively is all about 'race' as mentioned before. The idea of togetherness shown in the novel and what the above quotes convey might be bliss but in the case of a war zone love has no destiny. In a country like Sri Lanka where life threatening and cruelest fears emerge love 
cannot grow. Ethnicity defiles the agents and succumb them to become examples of torture. Had anything gone wrong with the trap or deliverance of the news about the trap both Kamala and Wasantha would have lost their lives in the most brutal ways. Wasantha describes the way one is tortured especially by his senior officer Kiriella “... I have seen you interrogate suspects, with a truncheon. They don't always survive, not intact anyway. You will get away with it too, because no one will know she was taken in" (De Silva, 2006, p. 387-388). In Karen Roberts ${ }^{\mathrm{xi}}$, novel July the two protagonists similarly like Wasantha and Kamala belonged to two different ethnicities the boy being a Tamil and girl a Sinhala. Unlike Wasantha and Kamala they had a tragic end to their love. The boy was murdered by the brother of the girl for being a Tamil and falling in love with her sister who is a Sinhalese. "Ordinarily, it would have been a match made in heaven. They were the right age, ... they were both bright and came from respectable middle-class families. However, Priyanthi was a Sinhalese girl and Niranjan was a Tamil boy and that difference was insurmountable" (Roberts, 2001, p. 218). Roberts describes the boy's brutal murder towards the end of the novel "When they finished, both Niranjan's legs were broken, his wrist and hand were smashed and his face was a bloody mess. The back of his head was soft with blood and brains. They stood back and admired their handiwork, then they left in search of more attacks" (Roberts, 2001, p. 354).

The objectification of ethno-nationalism continues till the end, when Kamala goes to Canada it is fleeing from her people and Wasantha missing in the final war at Elephant Pass, arises suspicion. "Still she was safe" (De Silva, 2006, p. 426) and ...Captain Ratnayake, has been declared missing in action during the evacuation of the camp at Elephant Pass" (De Silva, 2006, p. 428 ). Earlier in the novel Wasantha explains to Kamala the rights of the government when a community acts against the government which is again ethno-nationalist. "Once an ethnic or religious group has taken arms against the government, then all the members of that group must be treated as suspect" (De Silva, 2006, p. 198). The same person forgets his responsibilities as a soldier for some time and acts irrational. The call for duty dissolves and his Sinhalese nationalism evaporates. To understand the difference between the communities let us understand the paragraph below that has been used by Hobsbwam in his introduction to "Nations and Nationalism since $1780 "$

The Tamil-speaking people in Ceylon constitute a nation distinct from that of the Singalese by every fundamental test of nationhood, firstly that of a separate historical past in the island at least as ancient and as glorious as that of the Singalese, secondly by the fact of their being a linguistic entity entirely different from that of the Sinhalese, with an unsurpassed classical heritage and a modern development of language which makes Tamil fully adequate for all present day needs, and finally by reason of their territorial habitation of definite areas (1992, p. 6).

Being a South Asian country Sri Lanka is tied to multi-culturalism and hence there is absence of "ethno-cultural homogeneity" which affected the country to form a unity to sustain the "political process" (Upreti, 2006, p. 537). But the idea of claiming Sri Lanka as theirs (Sinhalese) is conflicting to the matter where the pre-occupancy of the island was held by tribal people. Not only in fictions but the history books are witness to the presence of tribal people before King Vijaya arrived. Wasantha is taken over by argument that "Even if, for the sake of the argument , we accept that the Sinhala came here first, do you think they can now claim exclusive rights to the entirety of the land, after both races have lived here for over two thousand years? Do you realize that by that argument the land should belong exclusively to the tribal people your Vijaya ${ }^{\text {xii }}$ 
displaced?" (De Silva, 2006, p. 153).The above argument rapidly exposes the facades of the Sinhala race and the attributes of the Tamils towards the same.

\section{Conclusion}

The question remains intact whether nationalism or ethnic nationalism delivers magnitude to a nation. Or does it really recompense loyalty towards the state. According to Roshwald "ethnic nationalism is seen as conducive to intolerant, chauvinistic, and authoritarian forms of government" (2001, p. 5). Had there been a secular and unbiased government in Sri Lanka the nation would have flourished without insurgencies and death. The novel also to an extent participates in dissolving the ethno-nationalist fervor through extremely opposite ethnicities that is the Sinhala and the Tamil but could have given more than just the story of the two protagonists and survival strategies in a jungle. The significance of Elephant Pass can be epitomized as a gateway to another world for Kamala and Wasantha away from war into peace in togetherness. De Silva did not enter the war zones instead he talked about internal wars that soldiers as human souls had to fight and the soldier could be of any side, could be a Tiger or a Sri Lankan soldier. Tigers and Sri Lankan Army were not just two groups but two identities, ethnic identities in particular. But ethnicity or "an ethnic group need not be a subordinate part of a larger political society but may be the dominant element within a state (the Chinese, English, or French, for example) or may extend across several states, as do the Arabs" (Connor, 1994, p. 43). Since both the communities are ethnic (Sinhalese and Tamil) both have a dominant role in society as well as politics. But nation and nationalism are the center and the communities are the periphery that always revolves around them without discontinuing and inquiring. And every ethno-nationalism theory in South Asia takes a different form than the European nationalism.

\section{Notes}

${ }^{\mathrm{i}}$ Sri Lankan novelist. He won the State Literary Award in 2003 for this novel.

ii Located at the gateway of Jaffna peninsula in Sri Lanka. It had an important military base since 176o when the Portuguese built a fort. And has regularly been the site of battles during the Civil War. Till 2000 the base was under the control of Sri Lankan Army. In April 2000 Liberation Tigers of Tamil Eelam took it from the army. Again in 2009 the Army recaptured the Elephant Pass just prior to the end of Civil War.

iii Liberation Tigers Tamil Eelam was formed by Velupalli Pbrabhakaran in 1976.

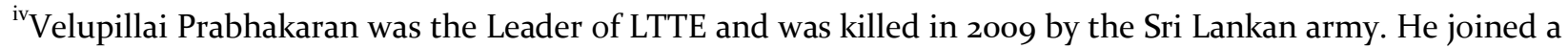
revolutionary group in university from where his journey as the most ferocious leader began.

${ }^{\mathrm{v}} 23^{\text {rd }}$ July 1983 also known as 'Black July' is a scar in the history of Sri Lanka. a thirteen member Sri Lankan Army soldiers were killed in an ambush in Jaffna. Later this incident resulted in a Tamil-Sinhala riot. Hence this day is also marked as the beginning of the twenty six years long Civil War.

${ }^{\mathrm{vi}}$ A religious and historical text written in the $5^{\text {th }}$ Century C.E. which is considered as the legitimation for an increasingly strident Sinhala nationalism.

vii The members of the LTTE are popularly known as Tigers.

viii $23^{\text {rd }}$ July is a black day in the Sri Lankan history. A bus with Sri Lankan Army soldiers were set on fire by the LTTE in Jaffan on the mentioned date in the year 1983 and as a result 13 soldiers died. 
${ }^{\mathrm{ix}}$ He was the Permanent Secretary of the Ministry of Defense in Sri Lanka from 2005 onwards. And he has been charged of war crimes

${ }^{\mathrm{x}}$ Here nationalism is being used in the context of ethnic-nationalism.

${ }^{x i}$ A fiction writer originally from Sri Lanka who is now a diaspora writer. She also uses Civil War as the background for her novels.

xii According to Sri Lankan history king Vijaya was sent in exile and he reached Sri Lanka from India and settled with his 700 men. And the present day Sinhalese is his people. Therefore they rightfully claim Sri Lanka to be their land.

\section{Reference}

Anderson, B. (1998). Imagined Communities: Reflections on the Origin and Spread of Nationalism. . London: Verso.

Cheran, R. (2003). Changing formations: Tamil nationalism and national liberation in Sri Lanka and the Diaspora(Unpublished thesis). Ontario York university. Retrieved April \& may, 2016.

Connor, W. (1994). A Nation Is a Nation, Is a State, Is an Ethnic Group, Is a ... In J. Hutchinson \& A.D. Smith(Eds.), Nationalism (pp. 37-46). Oxford: Oxford University Press.

De Silva, N. (2006). The road from Elephant pass. Sri Lanka: VijithaYapa Publications.

Dusche, M. (2010). Origins of Ethnic Nationalism in Germany and Repercussions in India. Economic and Political Weekly, 45(22), 37-46. Retrieved August 23, 15.

Gellner, E., \& Breuilly, J. (2013). Nations and nationalism. Malden, MA: Blackwell Publishing.

Goonetilleke, D. C. (2007). Sri Lankan English literature and the Sri Lankan people: 1917-2003. Colombo: Vijitha Yapa.

Hettige, S. T. (2004). Economic Policy, Changing Opportunities for Youth, and the Ethnic Conflict in Sri Lanka. In Economy, Culture, and Civil War in Sri Lanka(pp. 115-132). Bloomington and Indianapolis: Indiana University Press.

Hobsbawm, E. J. (1992). Nations and nationalism since I780 Programme, myth, reality. London: Cambridge U Press.

Kedourie, E. (1994). Nationalism and Self-Determination. In In J. Hutchinson \& A.D. Smith(Eds.), Nationalism (pp. 49-54). Oxford: Oxford University Press.

Maas, W. (n.d.). Emerging Themes and Issues in Ethnicity, Nationalism, and Migration Research. Ethnicity, nationalism, and migration research,1348-1359.

Mohan, R. (2014). The Seasons of Trouble: Life Amid the Ruins of Sri Lankan Civil War. London: Verso.

Munaweera, N. (2013) Island of a Thousand Mirrors. India: Hachette India.

Peebles, P. (2006). The History of Sri Lanka. Westport, CT: Greenwood Press.

Rampton, D. (2011). Deeper hegemony: the politics of Sinhala nationalist authenticity and the failures of power-sharing in Sri Lanka. Commonwealth \& Comparative Politics, 49(2), 245-73. Web.

Rieffer, B. A. J. (2003). Justifying Religious Nationalism in Historical and Contemporary times. Lincoln: University of Nebraska.

Roberts, K. (2001). July. London: Pheonix.

Roshwald, A. (2001). Ethnic nationalism and the fall of empires: central Europe, Russia, and the Middle East, 1914-1923. Psychology Press.

Syed, M.H. (2007). World Infopaedia: Sri Lanka. India: Pragun Publication.

Thapar, R., Noorani, A. G., \& Menon, S. (2016). On nationalism. New Delhi: Aleph.

Upreti, B. C. (2006). Nationalismin South Asia: Trendsand Interpretations. The Indian Journal of Political Science, 76(3), 535-44.

Weiss, G. (2012). The Cage: The Fight for Sri Lanka and the Last Days of the Tamil Tigers. London: Vintage Books. 